\title{
Prevalence of Vitamin D deficiency in a multiracial female population in KwaZulu-Natal province, South Africa
}

\author{
Yeshnee Naidoo $^{a *}$, Jagidesa Moodley ${ }^{b}$, Lorna Madurai ${ }^{c}$ and Thajasvarie Naicker ${ }^{a}$ \\ ${ }^{a}$ Discipline of Optics and Imaging, University of KwaZulu-Natal, Durban, South Africa \\ ${ }^{b}$ Women's Health and HIV Research Group, Department of Obstetrics and Gynaecology, University of KwaZulu-Natal, Durban, South Africa \\ 'Global Clinical and Virology Laboratory, Amanzimtoti, Durban, South Africa \\ *Corresponding author, email: 204003110@stu.ukzn.ac.za

Objective: Vitamin D deficiency is a global health issue affecting many countries, especially those in temperate climates. The aim of this study was to determine the prevalence of Vitamin D deficiency and level of 25-hydroxyvitamin D [25(OH)D] in females categorised by age and race.

Methods: The study was performed between January 2015 and January 2016. This study consisted of 1976 females stratified by age into $<18$, reproductive age $(18-45)$ and $>45$ years. Demographic variables were recorded and serum $25(\mathrm{OH}) \mathrm{D}$ levels measured by chemiluminescent emission.

Results: The predictors of lower 25(OH)D levels included age and race, $(p<0.0001$ for each predictor). Approximately $46 \%$ of females had $<20 \mathrm{ng} / \mathrm{ml} 25(\mathrm{OH}) \mathrm{D}$ level, the majority of whom were Indian (35\%). The 25(OH)D level varied by race (White $27.33 \mathrm{ng} / \mathrm{ml}$; Black $23.43 \mathrm{ng} / \mathrm{ml}$ and Indian $15.05 \mathrm{ng} / \mathrm{ml} ; p<0.0001)$. In the <18-year age category, White and Black women had significantly higher $25(\mathrm{OH}) \mathrm{D}$ levels when compared with Indian women $(38.25 \mathrm{ng} / \mathrm{ml} \mathrm{vs} .37 .51 \mathrm{ng} / \mathrm{ml} \mathrm{vs} .13 .68 \mathrm{ng} / \mathrm{ml}$ respectively; $p<0.0001)$. Similarly, in the reproductive age category $(18-45$ years); White $(27.63 \mathrm{ng} / \mathrm{ml})$ and Black $(20.93 \mathrm{ng} / \mathrm{ml})$ women had a significantly higher $25(\mathrm{OH}) \mathrm{D}$ level compared with Indian $(13.15 \mathrm{ng} / \mathrm{ml})$ women $(p<0.0001)$. Moreover, similar data were observed within the $>45$-year age category, where the White and Black women had higher 25(OH)D levels compared with Indian women $(25.46 \mathrm{ng} / \mathrm{ml}$ vs. $22.73 \mathrm{ng} / \mathrm{ml}$ vs. $17.04 \mathrm{ng} / \mathrm{ml} ; p<0.0001)$ respectively. Irrespective of age category, severe vitamin D deficiency was highest amongst Indian females.

Conclusion: This study demonstrates a significant difference in $25(\mathrm{OH}) \mathrm{D}$ concentration in healthy females living in Durban, with Indians presenting with the highest vitamin $D$ deficiency. These findings clearly highlight the need for a policy on vitamin $D$ supplementation and/or fortification of food. Further studies are under way to assess the genetic predisposition of women to vitamin D deficiency.

Keywords: Vitamin D, vitamin D deficiency, race, age

\begin{abstract}
Introduction
Vitamin $D$ is an essential nutrient that is required for overall human well-being, and in particular for bone and muscular health. However, vitamin D deficiency (VDD) is a worldwide problem, affecting individuals who are dark skinned, have diets deficient in vitamin $D$, who live in latitudes far from the equator and those with cultural apparel covering the body because of sociocultural practices. Some $90 \%$ of vitamin D is synthesised in the skin via exposure to ultraviolet radiation, therefore apart from a vitamin $\mathrm{D}$ deficient diet the commonest cause of vitamin $\mathrm{D}$ deficiency (VDD) is lack of exposure of skin to sunlight. ${ }^{1,2}$
\end{abstract}

Vitamin $D$ is present in two forms, namely vitamin $D_{2}$ (ergocalciferol) and vitamin $D_{3}$ (cholecalciferol). Vitamin $D_{3}$ is derived from 7-dehydrocholesterol by ultraviolet irradiation of the skin. Vitamin $D_{3}$ is also present in oily fish whilst $D_{2}$ is found in plants ${ }^{3}$. Both precursors are transported to the liver and are synthesised to 25-hydroxyvitamin D [25(OH)D] and 1,25-hydroxyvitamin D $[1,25(\mathrm{OH}) 2 \mathrm{D}] .^{1,2}$

Vitamin D deficiency triggers an increase in production of parathyroid hormone (PTH), which is required for calcium metabolism. An elevation of PTH results in an increase in mobilisation of calcium from increased renal production of $1,25(\mathrm{OH}) \mathrm{D}$; however, due to its short half-life, $25(\mathrm{OH}) \mathrm{D}$ is the element that is used to measure vitamin D levels. ${ }^{4,5}$
The circulating levels of 25(OH)D used to define VDD are controversial, with varying reference ranges used to assess serum concentration each based on the type of assay. Nevertheless, internationally a value of $<50 \mathrm{nmol} / \mathrm{l}(<20 \mathrm{ng} / \mathrm{ml})$ is generally regarded as an index of VDD. ${ }^{4,5}$

Vitamin $\mathrm{D}$ deficiency has an adverse clinical effect on children and adults. In children, VDD causes rickets and abnormal growth development, whilst in adults it is associated with a range of conditions such as multiple sclerosis, osteoporosis and cardiovascular diseases. ${ }^{6,7}$ VDD is also linked to a host of chronic diseases such as auto-immune disease, cancer and insulin resistance. ${ }^{8,9}$ Apart from a poor diet, risk factors for VDD include age, obesity, dark skin pigmentation, race, cultural/religious attire and a lack of adequate exposure to sunlight. $^{10}$

The prevalence of VDD is reported to be increased amongst adolescents. ${ }^{11}$ In a study carried out in Boston, young adults $(24 \% ; n=307)$ were shown to be vitamin D deficient with the highest prevalence occurring in adults of African descent. ${ }^{12}$ Vitamin $D$ deficiency is also reported to be more common in females. ${ }^{13,14}$ A study conducted in Brazil showed that the majority of women with VDD were of reproductive age whilst an Iranian study with a large sample size of 1111 participants also reported a higher prevalence of VDD in females. ${ }^{15,16}$ 
Studies on VDD have been conducted in high-income countries, on both native and migrant populations, in Middle Eastern countries and in various geographical regions of the Indian sub-continent. There is a scarcity of data on VDD from countries in sub-Saharan Africa. ${ }^{17,18}$ A number of studies report that darkskinned individuals who have migrated to countries at higher latitudes have VDD in comparison with the native population. ${ }^{17,18}$ In addition, a study conducted within the nine provinces of South Africa showed that VDD varies according to race and gender. However, the sample size in the different population groups in all nine provinces was small and failed to show statistical significant correlations based on gender, race and reproductive age. $^{19}$

The aim of the current study therefore was to assess the prevalence of VDD amongst the female population group of the different racial groups in the province of KwaZulu-Natal (KZN), South Africa.

\section{Methods}

\section{Study population}

Ethical permission was obtained from the biomedical research ethical committee at the University of KwaZulu-Natal (BREC reference number BE448/16).

A retrospective population-based study was conducted from January 2015 to January 2016 in Durban and surrounding areas. The study population consisted of a total of 1976 females born in South Africa. Only participants defined as Black, White and Indian South African population groups were included in the study. Each group was further stratified by age into: less than 18 years, within 18-45 years old (reproductive age) and older than 45 years old. The province of KwaZuluNatal has a subtropical climate with hot and humid summers and warm and dry winters that are snow and frost free.

All blood samples were sent from general practitioners and were non-hospitalised females. The general practitioners requested vitamin $D$ levels as a general test and not for specific reasons.

Clinical, demographic and biochemical data were obtained from a large private laboratory service within the province.

\section{Measurement of serum vitamin $D$}

Initially, serum samples $(15 \mu \mathrm{l})$ were incubated with dithiothreitol $(1 \mathrm{~g} / \mathrm{l}, \mathrm{pH} 5.5)$ and sodium hydroxide $55 \mathrm{~g} / \mathrm{l}$ to release the bound vitamin $D(25-\mathrm{OH})$ from the vitamin $D$ binding protein. Thereafter, the pre-treated samples were incubated in ruthenium labelled vitamin $D$ binding protein to form the complex between vitamin $D(25-\mathrm{OH})$ and ruthenylated vitamin $D$ binding protein. Subsequently, streptavidin-coated micro particles were incubated with vitamin $\mathrm{D}(25-\mathrm{OH})$ labelled biotin forming a ruthenium vitamin $\mathrm{D}$ binding protein and biotinylated vitamin $\mathrm{D}(25-\mathrm{OH})$ complex. The reaction mixture was then aspirated into the measuring cell where the micro particles were magnetically captured onto the surface of the electrode. Unbound substances were removed. Chemiluminescent emission was measured on the Cobas machine (E411; Roche Diagnostics, Japan) and the level of 25-hydroxyvitamin D was extrapolated from a calibration curve.

We used the following range for vitamin $D$ status ${ }^{19}$

- Severe vitamin D deficiency: 5-10 ng/ml;
- Vitamin D deficiency: $10-20 \mathrm{ng} / \mathrm{ml}$;

- Suboptimal vitamin D: $20-30 \mathrm{ng} / \mathrm{ml}$;

- Optimal vitamin D: $30-50 \mathrm{ng} / \mathrm{ml}$.

\section{Statistical analysis}

Statistical analysis was performed using GraphPad Prism version 5.01 (https://www.graphpad.com/scientific-software/prism/). A normality test was used to determine data distribution. Analysis of variance (ANOVA) was performed to evaluate differences in 25 $(\mathrm{OH}) \mathrm{D}$ for non-parametric data (median \pm interquartile range).

Dunn's multiple comparison test was used for comparisons across the groups. A two tailed $p$-value where $p<0.0001$ was considered significant.

\section{Results}

\section{Study population}

\section{Patient demographics}

The study population consisted of a total of 1976 participants, the demographics of whom are described in Table 1.

Females were stratified by age and ethnicity as follows:

- $<18$ years: Black (0.8\%), White (0.5\%) and Indian (2.3\%);

- 18-45 years: Black (15\%), White (8.7\%) and Indian (24\%);

- > 45 years: Black (11.7\%), White (10.5\%) and Indian (26\%).

Figure 1 shows that the median interquartile of $25(\mathrm{OH}) \mathrm{D}$ levels in the study population were as follows: Black $(23.43 \mathrm{ng} / \mathrm{ml})$, White $(27.33 \mathrm{ng} / \mathrm{ml})$ and Indian females $(15.05 \mathrm{ng} / \mathrm{ml})$.

Figure 2 represents 25(OH)D levels among females who are less than 18 years old and is categorised according to ethnic group. The 25(OH)D median was Black $(38.25 \mathrm{ng} / \mathrm{ml})$, White $(37.51 \mathrm{ng} /$ $\mathrm{ml})$ and Indian (13.68 $\mathrm{ng} / \mathrm{ml})$ females.

Figure 3 represents 25(OH)D levels among females of reproductive age categorised according to ethnicity. The $25(\mathrm{OH}) \mathrm{D}$ median was Black $(20.93 \mathrm{ng} / \mathrm{ml})$, White $(27.63 \mathrm{ng} / \mathrm{ml})$ and Indian $(13.15 \mathrm{ng} / \mathrm{ml})$ females.

Table 1: Age category, ethnicity of study population and median 25 $(\mathrm{OH}) \mathrm{D}$

\begin{tabular}{llc}
\hline Characteristics & No. (\%) & Median 25(OH)D \\
\hline Total number of females & 1976 & \\
\hline Age and ethnicity: & & \\
\hline Less than 18 years & $72(3.6)$ & \\
\hline Black & $17(0.8)$ & 38.25 \\
White & $10(0.5)$ & 37.51 \\
\hline Indian & $45(2.3)$ & 13.68 \\
\hline Reproductive age 18-45 years old & $947(47)$ & \\
\hline Black & $299(15)$ & 20.93 \\
White & $173(8.7)$ & 27.63 \\
\hline Indian & $475(24)$ & 13.51 \\
Older than 45 years old & $957(48)$ & \\
\hline Black & $232(11.7)$ & 22.73 \\
\hline White & $208(10.5)$ & 25.46 \\
\hline Indian & $517(26)$ & 17.04 \\
\hline
\end{tabular}




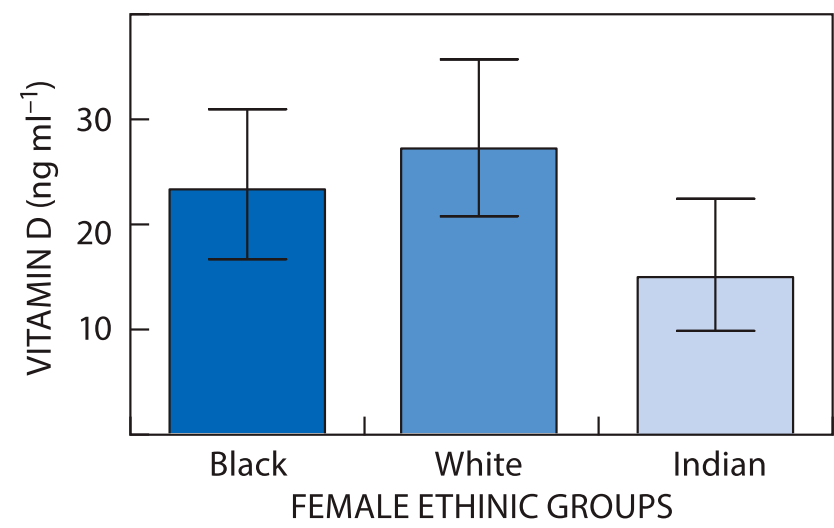

Figure 1: 25(OH)D level and ethnicity of study participants.

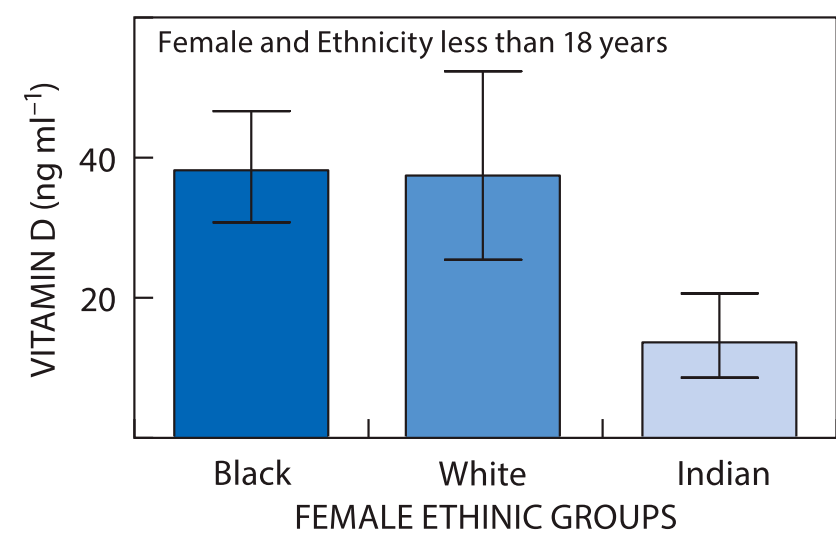

Figure 2: 25(OH)D levels among $<18$-year-olds.

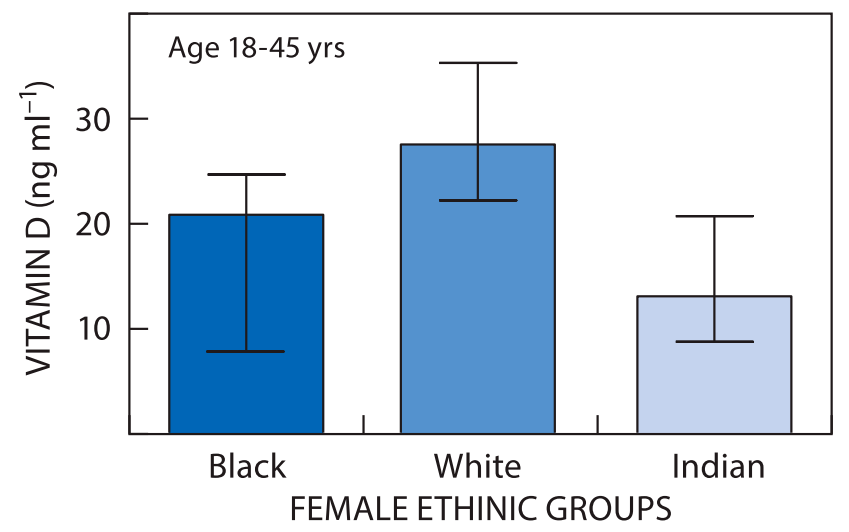

Figure 3: 25(OH)D among 18-45-year-olds.

Figure 4 represents 25(OH)D levels among females who were older than 45 years old categorised according to ethnicity. The $25(\mathrm{OH}) \mathrm{D}$ median was Black $(22.73 \mathrm{ng} / \mathrm{ml})$, White $(25.46 \mathrm{ng} / \mathrm{ml})$ and Indian (17.04 ng/ml) (Tables 2 and 3 ) females.

\section{$25(\mathrm{OH}) \mathrm{D}$ levels}

$25(\mathrm{OH}) \mathrm{D}$ levels varied within the racial groups (Figure 1). The White group had significantly higher $25(\mathrm{OH}) \mathrm{D}$ levels compared with the Black and Indian groups $(27.33 \mathrm{ng} / \mathrm{ml} ; 23.43$ and $15.05 \mathrm{ng} / \mathrm{ml}$ respectively; $p<0.0001$ ). Histograms depicting 25 $(\mathrm{OH}) \mathrm{D}$ level in each population group by age are outlined in

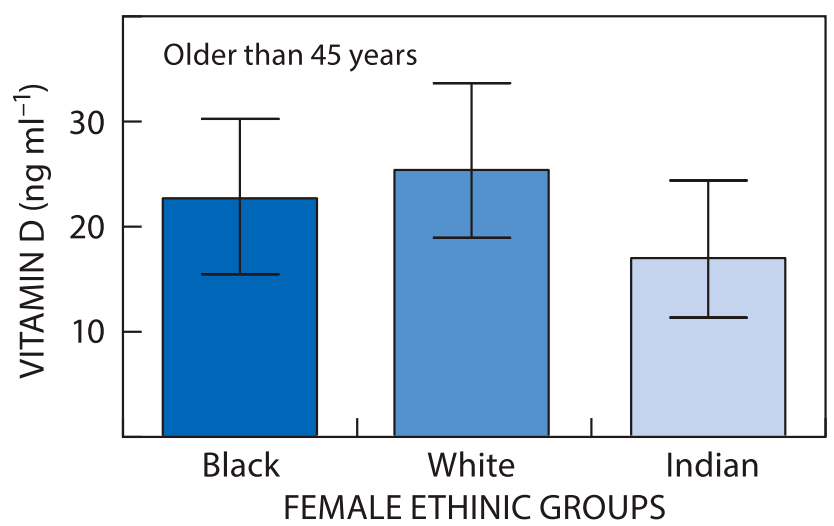

Figure 4: 25(OH)D levels among $>45$ year-olds.

Table 2: Frequency of $25(\mathrm{OH}) \mathrm{D}$ deficiencies among the female population

\begin{tabular}{|c|c|c|c|}
\hline Age and ethnicity & No. \% & $\begin{array}{c}5-10 \mathrm{ng} / \\
\mathrm{ml}\end{array}$ & $\begin{array}{c}10-20 \mathrm{ng} / \\
\mathrm{ml}\end{array}$ \\
\hline Less than 18 years & $72(3.6)$ & & \\
\hline Black & $17(0.8)$ & $1(0.05)$ & 0 \\
\hline White & $10(0.5)$ & 0 & 0 \\
\hline Indian & $45(2.3)$ & $12(0.6)$ & $21(1.06)$ \\
\hline $\begin{array}{l}\text { Reproductive age } 18-45 \\
\text { years }\end{array}$ & 947 (47) & & \\
\hline Black & $299(15)$ & $10(0.5)$ & $97(4.9)$ \\
\hline White & $173(8.7)$ & $5(0.25)$ & $22(1.1)$ \\
\hline Indian & $475(24)$ & $154(7.8)$ & $194(9.8)$ \\
\hline Older than 45 years & $957(48)$ & & \\
\hline Black & $232(11.7)$ & $22(1.1)$ & $70(3.5)$ \\
\hline White & $208(10.5)$ & $16(0.8)$ & $41(2.0)$ \\
\hline Indian & $517(26)$ & $103(5.2)$ & $211(10.6)$ \\
\hline
\end{tabular}

Table 3: Vitamin D deficiency, ethnicity and age categories

\begin{tabular}{|c|c|c|c|c|}
\hline \multirow[b]{2}{*}{$\begin{array}{l}\text { Vitamin D } \\
\text { deficiency and age }\end{array}$} & \multicolumn{4}{|c|}{ Ethnic groups } \\
\hline & Black & White & Indian & $\begin{array}{c}p- \\
\text { value }\end{array}$ \\
\hline \multicolumn{5}{|l|}{$\begin{array}{l}\text { Less than } 18 \text { years } \\
n=72 \text { : }\end{array}$} \\
\hline $\begin{array}{l}5-10 \mathrm{ng} / \mathrm{ml} \text { (severe } \\
\text { vitamin } \mathrm{D} \text { deficiency) }\end{array}$ & $1(0.05)$ & 0 & $12(0.6)$ & 0.0001 \\
\hline $\begin{array}{l}\text { 10-20 ng/ml (vitamin } \\
\text { D deficiency) }\end{array}$ & 0 & 0 & 21 (10.6) & 0.0001 \\
\hline \multicolumn{5}{|l|}{$\begin{array}{l}\text { Reproductive age } \\
\text { (18-45 years) } n=947 \text { : }\end{array}$} \\
\hline $\begin{array}{l}5-10 \mathrm{ng} / \mathrm{ml} \text { (severe } \\
\text { vitamin } \mathrm{D} \text { deficiency) }\end{array}$ & $10(0.5)$ & $\begin{array}{l}5 \\
(0.25)\end{array}$ & $154(7.8)$ & 0.0001 \\
\hline $\begin{array}{l}\text { 10-20 ng/ml (vitamin } \\
\text { D deficiency) }\end{array}$ & $97(4.9)$ & $\begin{array}{l}22 \\
(1.1)\end{array}$ & $194(9.8)$ & 0.0001 \\
\hline \multicolumn{5}{|l|}{$\begin{array}{l}\text { Older than } 45 \text { years } \\
n=957:\end{array}$} \\
\hline $\begin{array}{l}5-10 \mathrm{ng} / \mathrm{ml} \text { (severe } \\
\text { vitamin } \mathrm{D} \text { deficiency) }\end{array}$ & $22(1.1)$ & $\begin{array}{l}16 \\
(0.8)\end{array}$ & $103(5.2)$ & 0.0001 \\
\hline $\begin{array}{l}10-20 \mathrm{ng} / \mathrm{ml} \text { (vitamin } \\
\mathrm{D} \text { deficiency) }\end{array}$ & $70(3.5)$ & $\begin{array}{l}41 \\
(2.0)\end{array}$ & 211 (10.6) & 0.0001 \\
\hline
\end{tabular}


Table 4: Mean age and 25(OH)D deficiency

\begin{tabular}{lc}
\hline Age and ethnicity & Mean age $(5-10 \mathbf{~ n g} / \mathbf{m l}$ and $10-20 ~ \mathbf{~} / \mathbf{m l})$ \\
\hline Less than 18 years old: & 11.3 \\
\hline Indian & \\
Reproductive age: & 32.3 \\
Indian & 35.0 \\
Black & 37.5 \\
White & \\
Older than 45 years old: & 58.8 \\
Indian & 57.3 \\
\hline Black &
\end{tabular}

Figure 2 (< 18 years), Figure 3 (18-45 years) and Figure 4 (> 45 years).

The mean age (range) per $25(\mathrm{OH}) \mathrm{D}$ thresholds per age category in each population group is outlined in Table 4.

\section{Age category $<18$ years}

In the $<18$ years age category, the $25(\mathrm{OH}) \mathrm{D}$ levels were severe vitamin $\mathrm{D}$ deficient $(n=12[0.6 \%])$ and vitamin $\mathrm{D}$ deficiency $(n=$ 21 [1.06\%]) in the Indian population group. However, within this age category, White and Black women had a significantly higher 25(OH)D level when compared with Indian women $(38.25 \mathrm{ng} / \mathrm{ml}$ vs. $37.51 \mathrm{ng} / \mathrm{ml}$ vs. $13.68 \mathrm{ng} / \mathrm{ml} ; p<0.0001$ ) respectively.

\section{Age category 18-45 years}

With regard to those in the reproductive age groups (18-45 years), White women had significantly higher $25(\mathrm{OH}) \mathrm{D}$ levels compared with both Black and Indian women $(27.63 \mathrm{ng} / \mathrm{ml}$ vs. $20.93 \mathrm{ng} / \mathrm{ml}$ vs. $13.15 \mathrm{ng} / \mathrm{ml} ; p<0.0001$ ) respectively.

The Indian group demonstrated severe vitamin $D$ deficiency $(n=154[7.8 \%])$ and vitamin D deficient $(n=194$ [9.8\%] 25 $(\mathrm{OH}) \mathrm{D}$ levels.

\section{Age category $>45$ years}

Similarly, in the $>45$-year age category, White and Black women had higher 25(OH)D levels compared with Indian women $(25.46 \mathrm{ng} / \mathrm{ml}$ vs. $22.73 \mathrm{ng} / \mathrm{ml}$ vs. $17.04 \mathrm{ng} / \mathrm{ml} ; \quad p<0.0001)$ respectively. The Indian group demonstrated severe vitamin $D$ deficiency $(n=103[5.2 \%])$ and vitamin D deficient $(n=211$ [10.6\%]) levels.

An overall comparison among all three groups indicate that the White population group had a significantly higher 25(OH)D level compared with the Black and Indian groups $(p<0.0001)$. However, the Black and White population group were severe vitamin $D$ deficiency $(1.1 \% ; 0.8 \%)$ and vitamin $D$ deficient (3.5\%; 2\%).

\section{Discussion}

The present study investigated the circulating level of $25(\mathrm{OH}) \mathrm{D}$ in a fairly large sample $(n=1976)$ of female Black, Indian and White South Africans. An overall comparison across all three racial groups indicatea that $25(\mathrm{OH}) \mathrm{D}$ levels were significantly higher in White compared with Black and Indian women $(p<$ 0.0001 ). We also report that Indian women have significantly higher levels of VDD compared with the White and Black groups irrespective of age (see Figure $1 ; p<0.0001$ ). These results of high VDD in Indian compared with White and Black women within South Africa are corroborated by another study. ${ }^{20}$ Associations between VDD and racial groups have also been reported in various other studies. ${ }^{12,18,19,21,22}$

More recently, George et al. (2013) found that the prevalence of VDD was higher among the Indian (15\%) compared with the African (3\%) population group in Johannesburg, irrespective of gender. These researchers have implicated the influence of sun exposure, season, dietary intake of calcium and vitamin $D$, total body fat and body fat distribution on $25(\mathrm{OH}) \mathrm{D}$ concentration and found levels of $<12 \mathrm{ng} / \mathrm{ml}$ in $28.6 \%$ of the Indian group in comparison with $5.1 \%$ of the Black group. ${ }^{20}$ These results correlate to both the Indian reproductive age (18-45 years) and $>45$-year age groups in the present study, which report severe VDD (13.0\%) and VDD (20.4\%) respectively.

Factors that may have contributed to the difference in $25(\mathrm{OH}) \mathrm{D}$ levels among the population groups enrolled in the current study include season, time of day, latitude, skin phenotype, sun exposure duration, type of clothing and use of sunscreens. ${ }^{11,19,23}$ Skin pigmentation is considered a determinant of 25(OH)D production. However, Bogh et al. (2010) examined baseline $25(\mathrm{OH}) \mathrm{D}$ in fair and dark skinned participants and found that post short-wave ultraviolet $B$ ray exposure (UVB), skin phenotype was not a determinant of $25(\mathrm{OH}) \mathrm{D}$ production whilst cholesterol varied with the duration of UVB exposure. ${ }^{21}$ Despite sunlight being mandatory for 25(OH)D synthesis, countries receiving high levels of sunlight such as Saudi Arabia, Qatar, United Arab Emirates, Turkey, Pakistan and Iran all report high VDD. ${ }^{16}$ Notably in the latter countries, socio-religious and cultural practices do not facilitate sufficient sun exposure, which is required for $25(\mathrm{OH}) \mathrm{D}$ synthesis. The use of traditional clothing that blocks ambient sunlight decreases cutaneous vitamin $\mathrm{D}$ production hence contributing to lower levels of $25(\mathrm{OH}) \mathrm{D}^{24}$ In a study assessing awareness of VDD (18-25 years) in women using the burqa, niqab, hijab and chador, many were unaware of the negative effect of this type of clothing. In Pakistan similar attire is used and VDD occurs in the majority of women of reproductive age (73\%). ${ }^{25}$

A high prevalence of VDD has been reported from various geographical areas in India among children, adolescents, young adults, pregnant women and lactating mothers and those $>50$ years old. ${ }^{26}$ Also, VDD is highly prevalent in Pakistan, Bangladesh, Nepal, Sri Lanka, Myanmar and Bhutan, countries with similar geographic and socioeconomic cultures. ${ }^{26,27}$ Similar to our study, Bandeira et al. (2006) report that an Indian group demonstrated a higher prevalence of VDD regardless of skin colour and sun exposure. ${ }^{18}$ Additionally, our results are corroborated by Balasubramanian et al. (2013) who reported a $50-90 \%$ prevalence of VDD in the Indian subcontinent, attributable to low dietary calcium along with skin colour and changing lifestyle. ${ }^{24}$ Nonetheless, the findings of our study show that, despite the westernised lifestyle in South Africa, Indian women have a higher degree of $25(\mathrm{OH}) \mathrm{D}$ deficiency. Also supporting this finding was the observation of vitamin $D$ deficiency in South Indians residing in the UK, where a low calcium intake diet, clothing and sun exposure were the influencing factors. ${ }^{28}$

Irrespective of migration, Indians worldwide adhere to similar cooking methods such as slow cooking and deep-frying. Vitamin $D$ is degradable at temperatures above $200^{\circ} \mathrm{C}$, gas cooking reaches a temperature of $1900^{\circ} \mathrm{C}$ and coal stove 300 $700^{\circ} \mathrm{C}$. When foods are deep fried, $25(\mathrm{OH}) \mathrm{D}$ is thermally degraded as it comes out of the cooking medium. ${ }^{29,30}$ This 
could be a contributing factor to vitamin $D$ deficiency in the current study. Moreover, Indians are predominantly vegetarians, hence their diet lacks $25(\mathrm{OH}) \mathrm{D}$. Foods of animal origin are rich in $25(\mathrm{OH}) \mathrm{D} .^{26}$ It must be noted, however, that in the present study it is likely that most Indians followed both animal and vegetarian diets. Therefore, diet is not solely responsible for the deficiency; genetic factors leading to vitamin D deficiency in Indians should also be considered. However, polymorphisms in 7 dehydroxylase reductase, DBP, 1 alpha hydroxylase, VDR, and 25, 24 hydroxylase have produced no clear link. ${ }^{31-33}$

Vitamin D deficiency among women of reproductive age has many clinical complications. The reproductive organs including the cervical epithelia, endometrial and epithelial cells of the fallopian tubes, ovaries, and pituitary glands contain receptors and enzymes that are involved in vitamin D metabolism. ${ }^{15}$ Vitamin D deficiency may also lead to infertility associated with chronic anovulation and endometriosis, pre-eclampsia and breast cancer. ${ }^{34-36}$ In the present study, Indian women demonstrated severe and deficient $25(\mathrm{OH}) \mathrm{D}$ levels compared with other racial groups. These results are corroborated by Capatina et al. (2014) who reported 25(OH)D insufficiency in postmenopausal women. ${ }^{37}$ The latter study emphasises the role of vitamin $D$ in women irrespective of their age and highlights the need for vitamin $\mathrm{D}$ supplementation in post-menopausal women.

In the $<18$-year age group, $41.1 \%$ of the Indian participants had severe vitamin D deficiency and VDD levels with the mean age reported at 11.3 years old. Only $1.35 \%$ of the Black group was VDD whilst none was reported in the White group (Figure 2). However, when stratified by race, a limitation of the study was the small sample size of $<18$-year age group. In the present study $41.1 \%$ of Indian children had $25(\mathrm{OH}) \mathrm{D}<$ $13 \mathrm{ng} / \mathrm{ml}$, therefore there is a need to assess the $25(\mathrm{OH}) \mathrm{D}$ levels in South African children, with a focus on the Indian group. Nonetheless, it is well documented that vitamin $D$ levels in children of Black race are associated with vitamin $D$ deficiency, and dark skin is a risk factor for vitamin D deficiency. ${ }^{25,26}$ Despite previous studies showing that those of Black ethnicity have lower levels of vitamin $D$, the results in the present study were dissimilar. ${ }^{22,38}$ Interestingly, a study conducted by Poopedi et al. (2009) ${ }^{39}$ reported vitamin D deficiency among children in Johannesburg, SA. The latter study correlates with our study in that $74 \%$ of the Black population aged 10 years had adequate vitamin D status.

The strengths of the present study include the large sample size, the standard methodology and the multi-ethnic nature of the study participants. Limitations of the study include variability in age, absence of calcium and PTH levels and the absence of a pregnant cohort. Additionally, pre-treatment and post-treatment comparison of vitamin D supplementation was not performed. Nonetheless, future research should include diet, body mass index, supplementation data and socioeconomic background as well as daily UVB exposure during different seasons within KwaZulu-Natal province, South Africa.

In conclusion, this study has shown that there are major differences in 25(OH)D concentrations in healthy adults living in Durban, with Indians showing the highest $25(\mathrm{OH}) \mathrm{D}$ deficiencies. The findings clearly demonstrate that a policy on vitamin D supplementation and or fortification of food should be strongly considered locally. Further studies are under way to assess the genetic predisposition of women to vitamin D deficiency.
Acknowledgements - The authors would like to thank the National Research Funding Institute for providing support for the project, including Prof T. Naicker, Prof J. Moodley and Dr Madurai for their continued support.

Disclosure statement - No potential conflict of interest was reported by the authors.

\section{References}

1. Holick MF. Vitamin D: A D-lightful solution for health. J Investig Med 2011;59(6):872-880.

2. Holick M. Vitamin D: A millenium perspective. J Cell Biochem 2003; 88 (2): 296-307.

3. Kulie T, Groff A, Redmer J, Hounshell J, Schrager S. Vitamin D: an evidence-based review. J Am Board Fam Med 2009;22(6):698-706.

4. Holick MF. Vitamin D deficiency. N Eng J Med 2007;357(3):266-281.

5. Heaney RP, Dowell MS, Hale CA, Bendich A. Calcium absorption varies within the reference range for serum 25-hydroxyvitamin D. J Am Coll Nutr 2003;22(2):142-146.

6. Holick MF. Resurrection of vitamin D deficiency and rickets. J Clin Invest 2006;116(8):2062-2072.

7. Chapuy MC, Schott AM, Garnero P, Hans D, Delmas PD, Meunier PJ. Healthy elderly French women living at home have secondary hyperparathyroidism and high bone turnover in winter. EPIDOS study group. J Clin Endocrinol Metab 1996;81(3):1129-1133.

8. Wu K, Feskanich D, Fuchs CS, Willett WC, Hollis BW, Giovannucci EL. A nested case-control study of plasma 25 -hydroxyvitamin $D$ concentrations and risk of colorectal cancer. JNCl: J Natl Cancer Inst 2007;99(14):1120-1129.

9. Cantorna MT, Zhu Y, Froicu M, Wittke A. Vitamin D status, 1,25-dihydroxyvitamin D3, and the immune system. Am J Clin Nutr 2004;80 (6): $1717 \mathrm{~S}-1720 \mathrm{~S}$.

10. Souberbielle JC. Epidemiology of vitamin-D deficiency. Geriatr Psychol Neuropsychiatr Vieil 2016;14(1):7-15.

11. Saintonge $S$, Bang $H$, Gerber LM. Implications of a new definition of vitamin $\mathrm{D}$ deficiency in a multiracial us adolescent population: the national health and nutrition examination survey III. J Pediatr 2009;123(3):797-803.

12. Gordon CM, DePeter KC, Feldman HA, Grace E, Emans SJ. Prevalence of vitamin $\mathrm{D}$ deficiency among healthy adolescents. Arch Pediatr Adolesc Med 2004;158(6):531-537.

13. Faghih $S$, Abdolahzadeh $M$, Mohammadi $M$, Hasanzadeh $J$. Prevalence of vitamin $D$ deficiency and Its related factors Among university students in shiraz, Iran. Int J Prev Med 2014;5(6):796-799.

14. Verdoia M, Schaffer A, Barbieri L, Di Giovine G, Marino P, Suryapranata $H$, et al. Impact of gender difference on vitamin $D$ status and its relationship with the extent of coronary artery disease. nutrition, metabolism, and cardiovascular diseases. Nutr Metab Cardiovasc Dis 2015;25(5):464-470.

15. Lopes VM, Lopes JR, Brasileiro JP, Oliveira I, Lacerda RP, Andrade $M R$, et al. Highly prevalence of vitamin D deficiency among Brazilian women of reproductive age. Arch Endocrinol Metab 2017;61(1):21-27.

16. Hovsepian S, Amini M, Aminorroaya A, Amini P, Iraj B. Prevalence of vitamin $D$ deficiency among adult population of isfahan city, Iran. $J$ Health Popul Nutr 2011; 29(2):149-155

17. Prentice A, Schoenmakers I, Jones KS, Jarjou LM, Goldberg GR. Vitamin D deficiency and Its health consequences in Africa. Clin Rev Bone Miner Metab 2009;7:94-106.

18. Bandeira F, Griz L, Dreyer P, Eufrazino C, Bandeira C, Freese E. Vitamin D deficiency: a global perspective. Arq Bras Endocrinol Metabol 2006;50:640-646.

19. Tietz NW, Burtis CA, Ashwood ER, Bruns DE. Tietz textbook of clinical chemistry and molecular diagnostics. St. Louis, Mo.: Elsevier Saunders; 2006.

20. George JA, Norris SA, van Deventer HE, Pettifor JM, Crowther NJ. Effect of adiposity, season, diet and calcium or vitamin $D$ supplementation on the vitamin $D$ status of healthy urban african and asianIndian adults. Br J Nutr 2014;112(4):590-599. 
21. Bogh MK, Schmedes AV, Philipsen PA, Thieden E, Wulf HC. Vitamin D production after UVB exposure depends on baseline vitamin D and total cholesterol but not on skin pigmentation. J Invest Dermatol 2010;130(2):546-553.

22. Harris SS. Vitamin D and african Americans. J Nutr 2006;136(4):11261129.

23. Harinarayan CV, Holick MF, Prasad UV, Vani PS, Himabindu G. Vitamin D status and sun exposure in India. Dermatoendocrinol 2013;5 (1):130-141.

24. Karthik S, Parkar B, Balasubramanian K. Awareness of vitamin D and its deficiency among burqa clad women in Navi Mumbai, India. Int $J$ Sci Res 2017;6(7):95-97.

25. Junaid K, Rehman A, Jolliffe DA, Wood K, Martineau AR. High prevalence of vitamin $D$ deficiency among women of child-bearing age in lahore Pakistan, associating with lack of sun exposure and illiteracy. BMC Womens Health 2015;15:83.

26. Gita R, Gupta A. Vitamin D deficiency in India: prevalence, causalities and interventions. Nutr 2014;6(2):729-775.

27. Akhtar S. Vitamin D status in south asian populations - risks and opportunities. Crit Rev Food Sc Nutr 2016;56(11):1925-1940.

28. Kift R, Berry JL, Vail A, Durkin MT, Rhodes LE, Webb AR. Lifestyle factors including less cutaneous sun exposure contribute to starkly lower vitamin D levels in U.K. South Asians Compared with the White Population. Br J Dermatol 2013;169(6):1272-1278.

29. Natri AM, Salo P, Vikstedt T, Palssa A, Huttunen M, Karkkainen MU, et al. Bread fortified with cholecalciferol increases the serum 25hydroxyvitamin $D$ concentration in women as effectively as a cholecalciferol supplement. J Nutr 2006;136(1):123-127.

30. Lu Z, Chen TC, Zhang A, Persons KS, Kohn N, Berkowitz R, et al. An evaluation of the vitamin D3 content in fish: Is the vitamin $D$ content adequate to satisfy the dietary requirement for vitamin $D$ ? J Steroid Biochem Mol Biol 2007;103(3-5):642-644.
31. McGrath JJ, Saha S, Burne THJ, Eyles DW. A systematic review of the association between common single nucleotide polymorphisms and 25-hydroxyvitamin D concentrations. J Steroid Biochem Mol Biol 2010;121(1):471-477.

32. Wang TJ, Zhang F, Richards JB, Kestenbaum B, van Meurs JB, Berry D, et al. Common genetic determinants of vitamin $D$ insufficiency: a genome-wide association study. Lancet 2010;376(9736):180-188.

33. McCullough ML, Bostick RM, Mayo TL. Vitamin D gene pathway poly morphisms and risk of colorectal, breast, and prostate cancer. Ann Rev Nutrit 2009;29:111-132.

34. Lerchbaum E, Rabe T. Vitamin D and female fertility. Curr Opin Obstet Gynecol 2014;26(3):145-150.

35. Colonese F, Lagana AS, Colonese E, Sofo V, Salmeri FM, Granese R, et al. The pleiotropic effects of vitamin $D$ in gynaecological and obstetric diseases: an overview on a hot topic. Biomed Res Int 2015;2015:986281.

36. Purswani JM, Gala P, Dwarkanath P, Larkin HM, Kurpad A, Mehta S. The role of vitamin $D$ in pre-eclampsia: a systematic review. $B M C$ Pregnancy Childbirth 2017;17:231.

37. Capatina C, Carsote M, Caragheorgheopol A, Poiana C, Berteanu M. Vitamin $D$ deficiency in postmenopausal women - biological correlates. Maedica (Buchar) 2014;9(4):316-322.

38. Rajakumar K, Moore CG, Yabes J, Olabopo F, Haralam MA, Comer D, et al. Effect of vitamin D (3) supplementation in black and in white children: A randomized, placebo-controlled trial. J Clin Endocrinol Metab 2015;100(8):3183-3192.

39. Poopedi MA, Norris SA, Pettifor JM. Factors influencing the vitamin D status off 11 year old urban South Africa children. Bone 2009;45(2): S84.

Received: 1-08-2018 Accepted: 25-10-2018 